\title{
RENCANA STRATEGIS PENGEMBANGAN BISNIS PT. SATYA ABADI VISIMED PERIODE 2014-2016 DENGAN MENERAPKAN MODEL BISNIS KANVAS
}

\author{
Temy Setiawan \\ Sekolah Tinggi Manajemen PPM \\ Rizal Zulkarnain \\ Sekolah Tinggi Manajemen PPM \\ Setiadi Djohar \\ Sekolah Tinggi Manajemen PPM
}

\begin{abstract}
Distribusi dan pemasaran alat-alat kesehatan saat ini merupakan bidang bisnis yang diperkirakan dapat terus berkembang seiring pertumbuhan kebutuhan pasar baru dan pengembangan pasar yang telah ada. Peluang ini dimanfaatkan oleh Graha Farma dengan mendirikan anak perusahaan, PT Satya Abadi Visimed (PT. SAV) yang memiliki aktifitas utama sebagai agen, pemasaran, importir, instalatir dan layanan purna jual peralatan kesehatan yang diharapkan dapat memberikan kontribusi terhadap perusahaan induk.. Persaingan yang sangat ketat serta ketergantungan yang sangat besar terhadap produsen alat kesehatan (prinsipal) dan para sumber daya kunci pemasaran menjadi permasalahan umum yang dapat menjadi ancaman bagi PT. SAV dalam mencapai target yang telah ditetapkan untuk menjaga pertumbuhan dan kelangsungan usahanya. Dengan menggunakan kanvas model bisnis Osterwalder dan Pigneur (2010), penulis berusaha untuk mengembangkan model bisnis PT. SAV dengan melakukan perubahan atau modifikasi pada setiap komponennya. Dari hasil pengembangan model bisnis tersebut ditemukan target pelanggan yang paling tepat untuk dilayani, beberapa nilai penawaran baru yang dapat diciptakan, aktifitas kunci dan saluranyang harus dijalankan dan pengembangan sumber daya untuk menangkap peluang atau mengatasi ancaman agar dapat meningkatkan pendapatan sekaligus melakukan kontrol terhadap biaya. Sehingga diharapkan PT. SAV akan unggul dalam persaingan dan dapat menunjukkan kinerja terbaik untuk menghasilkan keuntungan yang terus meningkat.
\end{abstract}

Kata Kunci:

BMC, Rencana Strategis Usaha,Pemasaran Alat Kesehatan. 


\section{PENDAHULUAN}

\subsection{Latar Belakang Masalah}

Meski pertumbuhan ekonomi Indonesia 2013 tidak mencapai target (5,9\% dari target 6,3\%) dan meningkatnya inflasi (9,2\% dari target 7,2\%), namun industri pelayanan kesehatan diperkirakan akan tetap bertumbuh dalam kurun waktu lima tahun ke depan. Terus meningkatnya kebutuhan masyarakat akan layanan kesehatan menjadi pendorong utama pertumbuhan industri jasa rumah sakit. Pemerintah memprioritaskan alokasi dana RAPBN 2014 kesehatan sebesar Rp 44,9 triliun, dengan prioritas untuk meningkatkan akses dan kualitas kesehatan masyarakat. Program jangka panjang asuransi pemerintah Jaminan Kesehatan Nasional (JKN) efektif berlaku mulai Januari 2014 akan memacu pertumbuhan fasilitas kesehatan.

Berdasarkan data Ditjen Bina Upaya Kesehatan Kemenkes Agustus 2012, jumlah rumah sakit di Indonesia sebanyak 1.997 (Tabel 1.) dengan total jumlah ranjang pasien sekitar 235.000 unit. Pada periode 2009 2012 mencapai 544 unit atau meningkat sekitar 36\% dimana 412 unit diantaranya sektor swasta. Jenis rumah sakit khusus bertumbuh signifikan, dari 333 pada 2010 menjadi 468 unit pada 2012.

Tabel 1.

Pertumbuhan Rumah Sakit

\begin{tabular}{|l|||c||c||c||c||c|}
\hline \hline Pengelola/Kepemilikan & $\mathbf{2 0 0 7}$ & $\mathbf{2 0 0 8}$ & $\mathbf{2 0 0 9}$ & $\mathbf{2 0 1 0}$ & $\mathbf{2 0 1 2}$ \\
\hline \hline Kemenkes \& Pemprov & 477 & 509 & 552 & 585 & 638 \\
\hline \hline TNI / Polri & 112 & 112 & 125 & 131 & 148 \\
\hline \hline BUMN / Dept.Lain & 78 & 78 & 78 & 78 & 79 \\
\hline Swasta & 652 & 673 & 768 & 838 & 1.132 \\
\hline \hline \multicolumn{1}{|c||}{ TOTAL } & $\mathbf{1 . 3 1 9}$ & $\mathbf{1 . 3 7 2}$ & $\mathbf{1 . 5 2 3}$ & $\mathbf{1 . 6 3 2}$ & $\mathbf{1 . 9 9 7}$ \\
\hline
\end{tabular}

Karena masih terbatasnya kemampuan produksi di dalam negeri maka pemenuhan kebutuhan alat kesehatan masih sangat bergantung pada impor. Produk dari negara Amerika Serikat, Jepang, Jerman, Italia dan beberapa negara Eropa Barat lain menjadi pilihan utama karena memiliki kualitas bahan yang baik, unjuk kerja yang prima, usia aktif pakai yang panjang dan terbukti lebih aman dalam penggunaannya. Sehingga selain untuk mendukung pelayanan, alat-alat kesehatan tersebut dimanfaatkan juga sebagai sarana pendidikan dan riset.

Persaingan yang ketat dalam pemasaran peralatan kesehatan menjadikan pengusaha harus lebih inovatif dalam melakukan promosi, membangun jaringan, untuk mencapai kesepakatan penjualan, dan membina hubungan jangka panjang dengan pelanggan. Berdasarkan data Ditjen Bina Produksi dan Distribusi Alat Kesehatan Kemenkes pada Februari 2013, jumlah pemohon ijin IUPAK 2011 sebanyak 496 perusahaan dan 2012 sebanyak 679 perusahaan. Peningkatan 42,65\% tersebut merupakan indikasi bahwa bisnis penyaluran peralatan kesehatan elektromedis, non elektromedis maupun in vitro laboratorium masih banyak diminati.

Semenjak krisis Eropa 2 tahun terakhir, pasar Asia termasuk Indonesia menjadi target utama ekspansi produsen alat dari negara maju. Oleh karena itu, perusahaan multinasional berdatangan membangun kantor representatif dan mencari 
mitra usaha distributor potensial untuk memperkuat merek di pasar Indonesia. Keberadaan perwakilan kantor tersebut tidak lain bertujuan untuk lebih memperluas jaringan distribusi pemasaran, melakukan kontak langsung dengan end user serta menyediakan pelayanan after sales yang lebih terpercaya agar produk menjadi lebih kompetitif.

\subsection{Rumusan Masalah}

PT.SAV telah beroperasi dalam bisnis peralatan kesehatan selama setahun, namun bagi Graha Farma sebagai holding sebenarnya bisnis healthcare bukan merupakan hal yang baru. Sebagai perusahaan yang bergerak di bidang pemasaran dan distribusi, aktifitas PT.SAV sangat bergantung kepada hubungan dengan para prinsipal untuk memenuhi kebutuhan pasar dan sumber daya kunci yang diandalkan dan sistem pemasaran.

Perusahaan harus dapat melepaskan diri dari ketergantungan ini dengan cara mencari peluang-peluang lain yang dapat menjadi sumber pendapatan dan membangun kompetensi inti sumber dayanya. Oleh karennya diperlukan penelitian untuk melihat model bisnis PT.SAV saat ini dan merancang model binisnya di masa yang akan datang.

\section{TINJAUAN PUSTAKA}

\subsection{Pengertian Strategi}

Pengertian strategi dikutip dari beberapa pendapat ahli seperti Chandler (1962), Mintzberg (1994), Fred R. David (2008), Hofer dan Schendel (1986), Hamel dan Prahalad (1995). Dari semua pendapat ini terlihat bahwa perencanaan strategis hampir selalu dimulai dari "apa yang dapat terjadi”, bukan dimulai dari “apa yang telah terjadi”.Strategi dibuat dengan tujuan untuk mencapai tujuan perusahaan di masa yang akan datang. Bukan berarti yang telah terjadi akan diabaikan, namun menjadi salah satu acuan untuk menyusun strategi. Perubahan tuntutan pasar danperilaku konsumen memerlukan peningkatan kompetensi inti perusahaan.

\section{$2.2 \quad$ Konsep Model Bisnis}

Beberapa ahli menjelaskan bahwa model bisnis dan strategi sebagai hal yang sama, namun ada pula yang menganggapnya sebagai hal yang berbeda. Pearce II dan Robinson (2011), menyatakan bagaimana perusahaan dapat meningkatkan keuntungannya. Timmers (1998), menjelaskan bagaimana produk, layanan dan informasi berjalan dapat menjadi sumber pendapatan dan memiliki potensi keuntungan.Rappa (2010), menyatakan sebuah metode untuk menjalankan bisnis dimana akan membuat perusahaan bertahan dengan sendirinya. Osterwalder dan Pigneur (2013), mendefinisikan model bisnis sebagai dasar pemikiran tentang bagaimana organisasi menciptakan, memberikan dan menangkap nilai.

Secara umum definisi yang dijelaskan mengenai model bisnis oleh beberapa ahli di atas sebenarnya tidaklah jauh berbeda. Inti utamanya adalah tentang bagaimana sebuah perusahaan dapat terus beraktifitas dan selalu meningkat keuntungannya sehingga dapat terus bertahan. Dalam penelitian ini penulis menggunakan teori Osterwalder dan Pigneur karena lebih komprehensif sehingga lebih praktis untuk diterapkan. Model ini memudahkan pelaku dan pengambil keputusan bisnis dalam merancang, mengevaluasi dan mengelola model bisnisnya. Osterwalder dan Pigneur menciptakan sebuah diagram yang didalamnya terdapat kerangka model bisnis yang disebut kanvas. Kanvas inilah yang membedakan definisi model bisnis ini dengan model bisnis lainnya. Dimana model bisnis lain harus didukung oleh teori lainnya, 
seperti value chain dan 5 forces, untuk menganalisis sebuah model bisnis.

Kerangka model bisnis kanvas terdiri dari sembilan komponen kotak yang saling terkait. Kotak-kotak ini berisikan elemenelemen penting yang menggambarkan bagaimana organisasi menciptakan benefit bagi pelanggan dan mendapat manfaat dari para pelanggan utamanya. Sembilan komponen tersebut mencakup empat area utama bisnis yaitu, Customer, Penawaran, Infra struktur dan Financial viability.

Sembilan komponen tersebut adalah customer segment, value proposition, channel, customer relationship, revenue stream, key resources, key activities, key partnership, dan cost structure. Model bisnis itu merupakan blue print bagi strategi untuk diimplementasikan melalui struktur, proses dan sistem organisasi.

\subsection{Analisis Lingkungan Eksternal} Lingkungan eksternal oleh Osterwalder \& Pigneur diibaratkan sebagai "ruang desain" atau konteks yang akan mempermudah untuk memahami atau mengadaptasi model bisnis dengan mempertimbangkan berbagai hal yang muncul di lingkungan bisnis kita misalnya kebutuhan untuk mendapatkan pelanggan baru, munculnya teknologi baru yang membuat produk kita menjadi usang, peraturan pemerintah, pesaing yang dominan danmasih banyak lagi. Oleh Osterwalder dan Pigneur (2013) pemetaan lingkungan ekternal yang dibagi menjadi empat bidang utama: kekuatan pasar, kekuatan industri, tren kunci, dan kekuatan ekonomi makro (Gambar 1.).

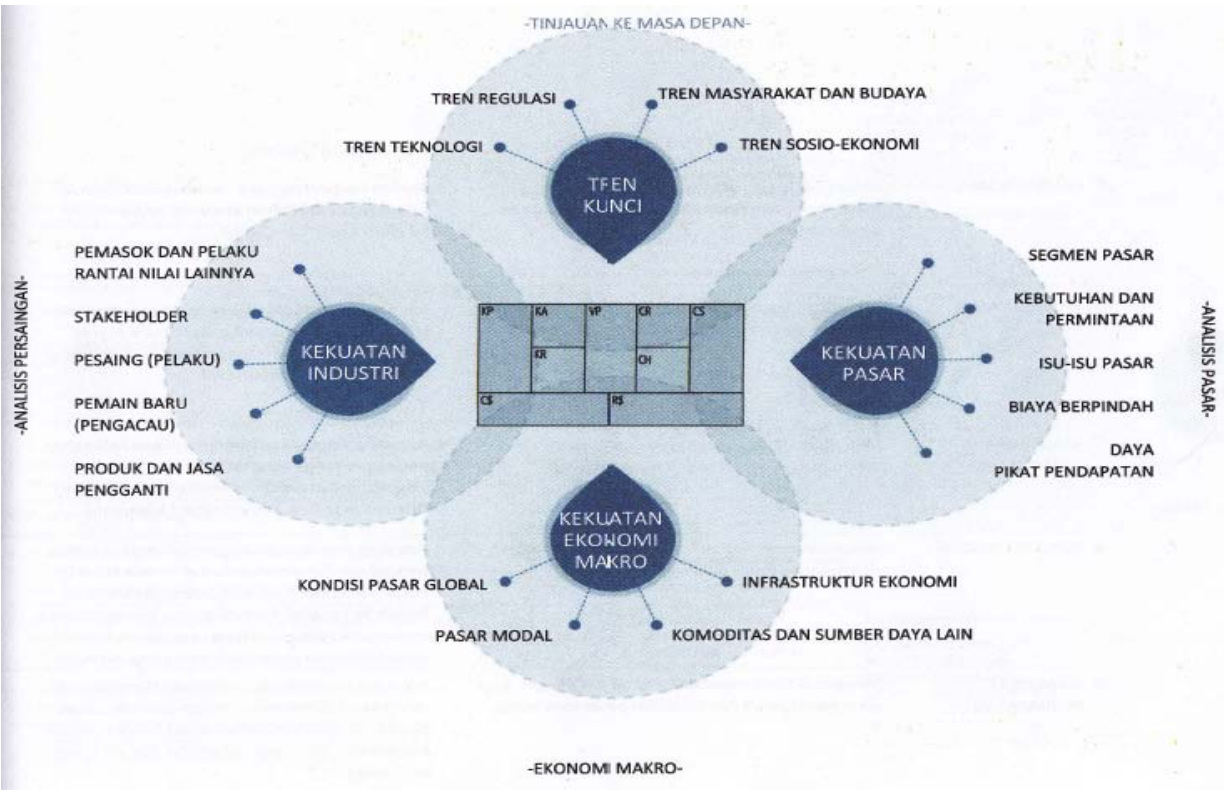

Gambar 1.

Lingkungan Eksternal Model Bisnis 


\subsection{Analisis Internal}

Analisis internal adalah analisis yang berfokus pada faktor kekuatan dan kelemahan internal yang memberikan keunggulan dan kekurangan tertentu bagi organisasi dalam upaya memenuhi kebutuhan target pasarnya. Analisis internal dilakukan terhadap sumber daya yang dimiliki perusahaan seperti sumber daya manusia, sistem operasi, teknologi, sarana dan sebagainya yang bertujuan untuk mengidentifikasi kekuatan dan kelemahan dalam bersaing.

Perbedaan penelitian ini dengan penelitian-penelitian lain adalah bahwa perusahaan yang menjadi obyek penelitian menggunakan pola bisnis business to business (B to B) kepada instansi rumah sakit yang menjadi pelanggan. Ciri khas bisnis B to B untuk peralatan investasi kesehatan adalah memerlukan tingkat layanan yang relatif kompleks, nilai transaksi besar namun memerlukan waktu yang cukup panjang untuk mendekatkan diri kepada pelanggan, terdapat beberapa pihak pengambil keputusan (pengguna, manajemen, bagian administrasi pembelian, panitia pengadaan, direksi) tingkat persaingan pemasok (supplier) yang tinggi, dan posisi tawar pembeli yang lebih kuat keputusan (pengguna, manajemen, bagian administrasi pembelian, panitia pengadaan, direksi) tingkat persaingan pemasok (supplier) yang tinggi, dan posisi tawar pembeli yang lebih kuat.

\section{METODOLOGI PENELITIAN}

\subsection{Jenis Penelitian}

Penelitian yang dilakukan penulis merupakan penelitian kualitatif. Dalam penelitian kualitatif, teori memiliki peranan yang sangat penting yang disusun melalui proses pengumpulan data, kategorisasi data dan pengembangan pola atau susunan teori.
Data kualitatif adalah data yang berbentuk kata, kalimat, skema dan gambar. Data-data didapat dari internal PT. SAV, asosiasi, literatur dan wawancara dengan narasumber.

\subsection{Pengembangan Kerangka Analisis}

Penelitian ini difokuskan untuk menentukan model bisnis yang akan tepat untuk PT. SAV dalam rangka menangkap peluang-peluang yang diharapkan dapat menjadi panduan untuk mengembangkan bisnisnya. Untuk mengetahui posisi perusahaan yang berkaitan dengan kekuatan, kelemahan, peluang dan ancaman ditinjau dari segi:

- Eksternal meliputi kondisi pasar, jumlah pesaing, perkembangan teknologi, kebijakan pemerintah, daya beli dan perilaku konsumen, lingkungan sosial, dan kondisi perekonomian.

- Internal perusahaan yang meliputi produk, harga, sumber daya, kekuatan finansial, penggunaan teknologi, serta mutu pelayanan.

Kerangka analisis dan pokok-pokok pembahasan dalam tesis ini dapat dijelaskan seperti pada Gambar 2. sebagai berikut : 


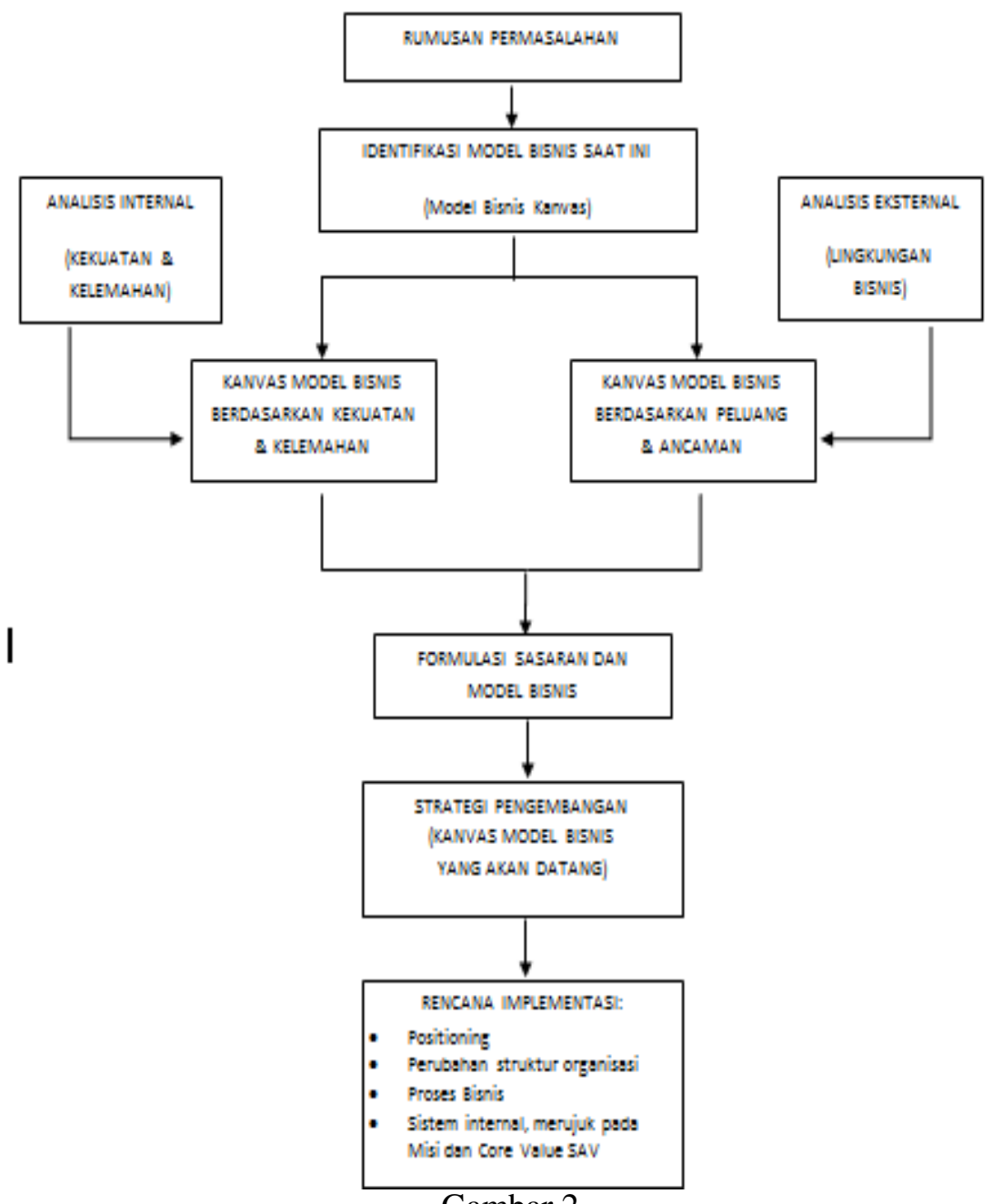

Gambar 2.

Kerangka Analisis Penelitian

\subsection{Pengumpulan Data}

\subsubsection{Data Primer}

Data Primer diperoleh melalui wawancara dengan pemegang keputusan perusahaan untuk mengetahui:

- Kondisi PT.SAV saat ini, apakah sudah berjalan sesuai dengan rencana yang dibuat oleh pemimpin puncak.

- Masalah yang dihadapi PT. SAV untuk mencapai target yang telah ditetapkannya. Apa yang menjadi kelemahan dan kekuatan perusahaan menurut sudut pandangnya.

- Pendapat narasumber mengenai kondisi lingkungan bisnisnya, peluang dan ancaman apa yang sedang dan akan dihadapi.

- Visi dan rencana PT.SAV di masa yang akan datang.

Pertanyaan pada wawancara berhubungan dengan identifikasi kelemahan dan kekuatan serta peluang dan ancaman 
didasarkan pada daftar panduan dari teori Osterwalder dan Pigneur (2013).

\subsubsection{Data Sekunder}

Pengumpulan data dilakukan dari sumber yang tersedia dari dalam (internal) maupun luar (eksternal) perusahaan berupa profil dan latar belakang perusahaan, visi/misi perusahaan, struktur organisasi, posisi perusahaan, publikasi perusahaan, jurnal penelitian, artikel, publikasi website, data asosiasi dan sumber lain yang relevan dengan penelitian.

\section{HASIL PENELITIAN}

\subsection{Model Bisnis Saat Ini}

Sebagai perusahaan yang telah berdiri selama setahun PT. SAV telah memiliki model bisnis yang secara umum tidak berbeda dengan pesaing. Berikut adalah penjelasan mengenai model bisnis PT. SAV saat ini.

\subsubsection{Customer Segment}

Sebagai perusahaan yang memasarkan peralatan kesehatan investasi, pelanggan utama yang dituju oleh PT. SAV adalah pasar institusi yaitu rumah sakit dan klinik sehingga bentuk kegiatan pemasaran dikategorikan sebagai Business to Business (B to B). Adapun rumah sakit yang dipilih menjadi sasaran utama PT. SAV adalah kelas A dan B yang memiliki standar pelayanan dan kelengkapan alat spesialis dan subspesialis yang luas.

\subsubsection{Value Proposition}

PT. SAV memiliki mitra keagenan peralatan elektromedis dengan standar kualitas Eropa dan Amerika Serikat yang sangat ketat dan selektif dalam menetapkan sertifikasi standarisasi dan kontrol mutu berdasarkan regulasi CE (Eropa) dan FDA (USA). Brand yang berasal dari Jerman dan
Amerika Serikat merupakan sebuah keunggulan nilai yang memberikan kemudahan untuk dapat diterima oleh pasar.

\subsubsection{Channels}

Dalam penyampaian value proposition-nya, PT. SAV secar arutin melakukan kegiatan komunikasi promosi brand dan produk kepada para dokter, operator maupun manajemen rumah sakit atau pemilik klinik. Kegiatan yang dilakukan dalam channels ini masih relatif sederhana dan hanya berfungsi untuk meningkatkan awareness. Media promosi yang digunakan masih tergolong konvensional bersifat komunikasi satu arah.

\subsubsection{Customer Relation}

Sebagai perusahaan yang baru berdiri, kegiatan customer relation yang dilakukan oleh PT. SAV lebih ditujukan untuk mengakuisisi pelanggan baru atau mengubah calon pelanggan agar dapat menjadi pelanggan aktual. Pelanggan yang dimaksud adalah user yang memiliki kemampuan untuk mempengaruhi pengambil keputusan dalam pembelian alat kesehatan baik di tempat ia bekerja maupun di lingkungan sejawatnya.

\subsubsection{Revenue stream}

Pendapatan utama PT.SAV diharapkan akan diperoleh dari penjualan alat-alat kesehatan investasi dan disposable, dan layanan perawatan dan perbaikan alat yang telah terpasang.

Saat penulisan ini pendapatan perusahaan belum maksimal karena pada tahun pertama berdiri PT. SAV masih fokus kepada pencarian partner bisnis, menjalankan kewajiban regulasi pendaftaran produk pada instansi terkait, melengkapi key resource dan upaya promosi memperkenalkan produk kepada para prospek rumah sakit dan asosiasi user 
melalui partisipasi pada beberapa kegiatan pameran.

\subsubsection{Key Resources}

Sumber daya utama yang vital bagi PT. SAVsebagai sebuah usaha baru adalah SDM yang kompeten dan berpengalaman yang akan diharapkan dapat mempercepat pergerakan aktifitas implementasi strategi perusahaan yang didukung oleh sarana kerja yang memadai. Selain memiliki key resources yang ada di dalam perusahaannya sendiri, PT. SAV juga memiliki key resources lain yaitu sister company Graha holding.

\subsubsection{Key Partner}

Alat-alat kesehatan yang dipasarkan PT. SAV diproduksi oleh perusahaan yang berasal dari Eropa dan USA dengan reputasi dunia yang baik dan kualitas yang teruji. Harga yang ditawarkan tentunya akan lebih mahal jika dibandingkan dengan peralatan yang diproduksi di Cina, India atau Brazil. Oleh karenanya dalam memasarkan produkproduknya, PT. SAV menentukan pasar rumah sakit tipe A dan B yang dalam memilih fasilitas alat kesehatan sangat mempertimbangkan kualitas untuk menjaga citra institusinya.

\subsubsection{Key Activities}

Kegiatan utama saat ini fokus kepada aktifitas pemasaran dan membangun brand awareness melalui personal selling dan pameran. Telah banyak kegiatan pameran asosiasi user yang diikuti dalam setahun terakhir sehingga produk yang dipasarkan oleh PT. SAV secara perlahan mulai dikenal. Hanya saja penyebaran promosi di daerah masih belum merata karena belum lengkapnya sumber daya marketing di beberapa cabang karena masih dalam tahap seleksi dan rekrutmen.

\subsubsection{Cost Structure}

Sebagai perusahaan yang baru berdiri pengeluaran dan investasi yang telah dibelanjakan PT. SAV cukup besar terutama untuk membangun aset gedung, sarana kerja, rekrutmen karyawan, promosi pameran, dan penyediaan alat demo untuk keperluan peraga promosi. Hal ini menjadikan beban awal operasional menjadi sangat besar bagi perusahaan yang berakibat pada struktur biaya yang tinggi sebesar 32,4\% sebagai pos biaya operasional pada struktur harga alat yang ditawarkan.

Pada Gambar 3. berikut ini ditunjukkan model bisnis PT. SAV saat ini. 


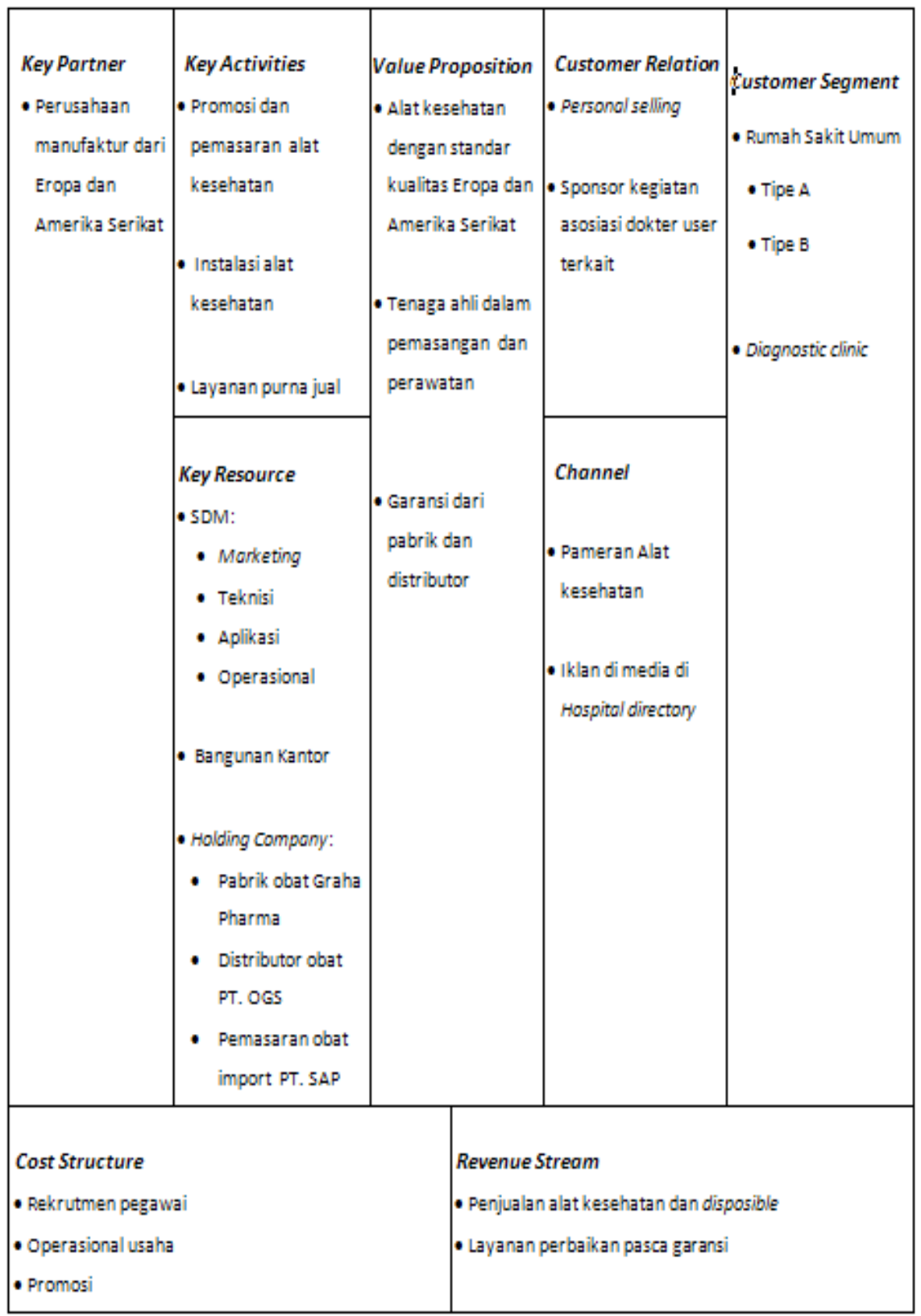

Gambar 3.

Model bisnis PT. SAV saat ini

\subsection{Analisis Internal Perusahaan}

Cara yang dilakukan untuk melakukan analisis internal adalah dengan mencari kekuatan dan kelemahan perusahaan dengan menanyakan pendapat dari internal perusahaan. Untuk keperluan tersebut, 
penulis telah menyiapkan serangkaian pertanyaan yang berhubungan dengan sembilan komponen model bisnis PT. SAV saat ini.

\subsubsection{Proposisi Nilai}

Pada pertanyaan mengenai propisisi nilai ini penulis berusaha untuk melihat kekuatan dan kelemahan yang terjadi pada komponen yang berhubungan dengan value proposition. Pihak manajemen PT. SAV merasa bahwa proposisi nilai yang ditawarkan saat ini masih belum dapat sesuai dengan kebutuhan pelanggan di tengah begitu ketatnya tekanan persaingan diantara para distributor alat kesehatan dan pertimbangan para target market yang menjadikan harga sebagai faktor penentu yang sangat dominan dalam pemilihan merek maupun produk. Namun demikian perusahaan mengambil keputusan untuk berfokus pada 4 bidang utama yang akan dilayani yaitu radiologi, bedah, ortopedi dan urologi guna mengerahkan sumber daya dan kompetensi agar menjadi lebih profesional dan ahli di bidang tersebut.

\subsubsection{Penilaian Biaya dan Pendapatan}

Pada pertanyaan mengenai penilaian biaya dan pendapatan penulis berusaha untuk melihat kelemahan dan kekuatan yang berhubungan dengan komponen revenue stream dan cost structure. PT. SAV sebenarnya memiliki keuntungan yang cukup besar dari hasil penjualan produk- produknya walaupun saat ini belum bisa dinikmati karena sebagian besar masih digunakan untuk biaya pembentukan perusahaan yang targetnya harus sudah dapat selesai pada awal tahun 2014.

\subsubsection{Infrastruktur}

Jalinan hubungan manajer kunci mitra produsen HOLOGIC dan DEL MEDICAL dengan General Manager dan
Direktur PT. SAV telah terbangun selama 10 tahun pada perusahaan distributor sebelumnya, sehingga telah terbentuk kepercayaan. Selain bermitra dengan produsen produk, perusahaan berencana akan bermitra dengan penyedia alat kesehatan di beberapa daerah di Indonesia sehingga memungkinkan memperoleh informasi tentang peluang kebutuhan alat kesehatan di luar jangkauan tim pemasaran.

\subsubsection{Hubungan dengan Pelanggan}

Pertanyaan menyoroti pada kelemahan dan kekuatan dari komponen customer segment, channel dan customer relation. Hubungan rumah sakit dengan supplier-nya tidaklah sering berpindah karena pada umumnya rumah sakit lebih senang untuk bekerjasama dengan distributor penyalur tunggal untuk mempermudah kontak layanan purna jual. Dalam memenuhi seluruh kebutuhan rumah sakit maka supplier akan membeli dari perusahaan lain dan bertindak sebagai mediator atau reseller.

Pada Gambar 4. berikut ini ditunjukkan model bisnis kekuatan dan kelemahan PT. SAV. 


\begin{tabular}{|c|c|c|c|c|}
\hline $\begin{array}{l}\text { Key Partner } \\
\text { Kekuatan: } \\
\text { + Brand berkualitas dan } \\
\text { memilikj reputasi } \\
\text { internasional } \\
\text { + Hubungan baik sehingga } \\
\text { mudahuntuk mendapatkan } \\
\text { dukungan harga } \\
\text { Kelemahan: } \\
\text { - Belum terlalu dikenal di } \\
\text { Indonesia }\end{array}$ & $\begin{array}{l}\text { Kelemahan: } \\
\text { - Belum dijalankan } \\
\text { dengan optimal } \\
\text { karena SDM yang } \\
\text { belum lengkap } \\
\text { - Mudah untuk ditiru } \\
\text { Key Resource } \\
\text { Kekuatan: } \\
\text { + Pengalaman \& } \\
\text { pendanaandari grup } \\
\text { usaha } \\
\text { +SDM kunci yang } \\
\text { berpengalaman } \\
\text { Kelemahan: } \\
\text { - Masih dalam tahap } \\
\text { pemenuhan tim } \\
\text { marketing cabang } \\
\text { - Marketing support } \\
\text { belum tersedia }\end{array}$ & $\begin{array}{l}\text { Volue Proposition } \\
\text { Kekuatan: } \\
\text { + Fokus dan expert } \\
\text { pada area } \\
\text { pemaseran } 4 \\
\text { bidang produk } \\
\text { Kelemahan: } \\
\text { - Proposisi nilai } \\
\text { belum sesuai } \\
\text { dengan } \\
\text { kebutuhan } \\
\text { pelanggan } \\
\text { - Fungsilayanan } \\
\text { masih bersifat } \\
\text { umum }\end{array}$ & $\begin{array}{l}\text { Custumer Relation } \\
\text { Kekuatan: } \\
\text { + Basis pelanggan yang } \\
\text { dilayani oleh grup Graha } \\
\text { +Jaringan pelanggan dari para } \\
\text { SDM yang berpengalaman } \\
\text { Kelemahan } \\
\text { - Basis pelanggan PT. SAV yang } \\
\text { masih minim } \\
\text { Channel } \\
\text { Kelemahan: } \\
\text { - Masih mengandalkan } \\
\text { saluran promiosi } \\
\text { konvensional } \\
\text { - Bersifat satuarah } \\
\text { - Partner di luar Jakarta } \\
\text { masihsedilit }\end{array}$ & $\begin{array}{l}\text { Kekuatan: } \\
\text { + Konsentrasi pada segmen } \\
\text { yang jelas,RS kelas A \& B } \\
\text { Kelemahan :. } \\
\text { - Untuk sektor pemerintah } \\
\text { bergantung pada } \\
\text { perusahaan tender }\end{array}$ \\
\hline \multicolumn{3}{|c|}{$\begin{array}{l}\text { Cost Structure } \\
\text { Kekuatan: } \\
\text { + Cost sharing untuk fungsi pendukung operasional grup } \\
\text { Kelemahan: } \\
\text { - Biaya investasi yang dikeluarkan relatif besar karena } \\
\text { masih dalam tahap penyediaan infrasituktur, pembentukan } \\
\text { organisasidan promosi }\end{array}$} & \multicolumn{2}{|l|}{ Revenue Stream } \\
\hline
\end{tabular}

Gambar 4.

Model Bisnis Kekuatan dan Kelemahan PT. SAV

\subsection{Analisis Eksternal Perusahaan}

Pemantauan, identifikasi dan analisa lingkungan eksternal sangat membantu perusahaan dalam rangka mengenali dan memprediksi faktor ketidakpastian. Kemampuan untuk memahami perubahan lingkungan akan menciptakan model bisnis yang efektif dan kompetitif. Dalam peneltian ini analisis lingkungan bisnis peralatan kesehatan merujuk kepada metode panduan pertanyaan Osterwalder dan Pigneur (2013). Pertanyaan yang diajukan meliput lingkungan eksternal perusahaan yang terdiri dari :

- Kekuatan Pasar yang didalamnya akan membahas tentang isu pasar, segmentasi pasar, kebutuhan dan permintaan, biaya pelanggan untuk melakukan perpindahan brand dan seberapa besar daya tarik pendapatan dari bisnis ini. 
- Kekuatan Industri yang akan membahas tentang para pelaku yang ada dalam bisnis ini, bagaimana peluang pemain baru untuk masuk dalam bisnis ini, produk atau jasa yang dapat menggantikan, pemasok dan pelaku rantai nilai, stakeholder.

- Tren Kunci yang didalamnya termasuk tren teknologi, tren regulasi, tren masyarakat dan budaya serta tren sosio ekonomi.

Dari analisis eksternal ini kita akan mengetahui potensi peluang dan ancaman yang akan dihadapi dalam menjalankan binis alat kesehatan.

\subsubsection{Potensi Peluang}

Pertumbuhan rumah sakit dalam 3 tahun terakhir begitu pesatnya. Hal ini berhubungan dengan semakin tingginya kepedulian masyarakat terhadap kesehatan. Penerapan JKS di 2014 dan persiapan menghadapi AFTA (Asean Free Trade Area) di 2015 juga mendorong pembangunan fasilitas rumah sakit. Rumah sakit yang telah beroperasi juga memerlukan peremajaan alatnya demi meningkatkan mutu layanan. Sektor perbankan juga memberikan sinyal positif dengan memberikan kemudahan peminjaman dana sebagai modal usaha dan investasi di sektor kesehatan.

\subsubsection{Potensi Ancaman}

Peluang bisnis yang besar berjalan seiring dengan makin tumbuh berkembangnya jumlah pesaing. Semakin banyaknya merek alat kesehatan yang menyasar pasar Indonesia membuka peluang bagi para distributor alat kesehatan baru yang beroperasi meramaikan situasi persaingan. Pemerintah juga mengetatkan proses regulasi pendaftaran produk kesehatan di Kemenkes dengan menerapkan sistem online. Hal ini akan mempersulit kesiapan pemasaran alat kesehatan khususnya pada instansi pemerintah karena proses registrasi berjalan lebih lama. Melemahnya kurs mata uang juga menjadikan harga peralatan melambung. Hal lain adalah tingginya biaya akuisisi SDM pemasaran berpengalaman.

Pada Gambar 5. berikut ini ditunjukkan model bisnis peluang dan ancaman PT. SAV. 


\begin{tabular}{|c|c|c|c|c|c|}
\hline 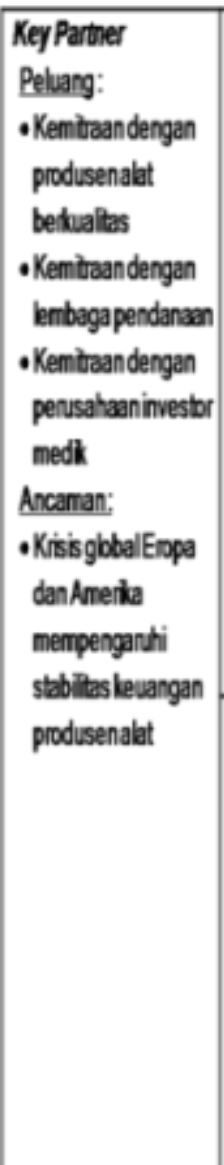 & 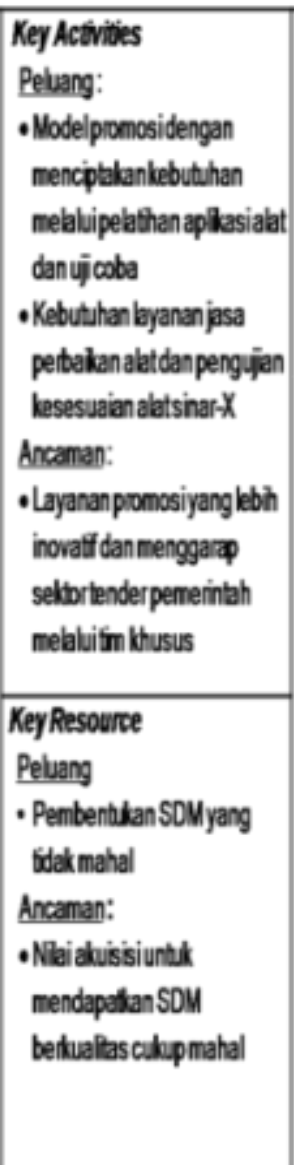 & \multicolumn{2}{|c|}{ 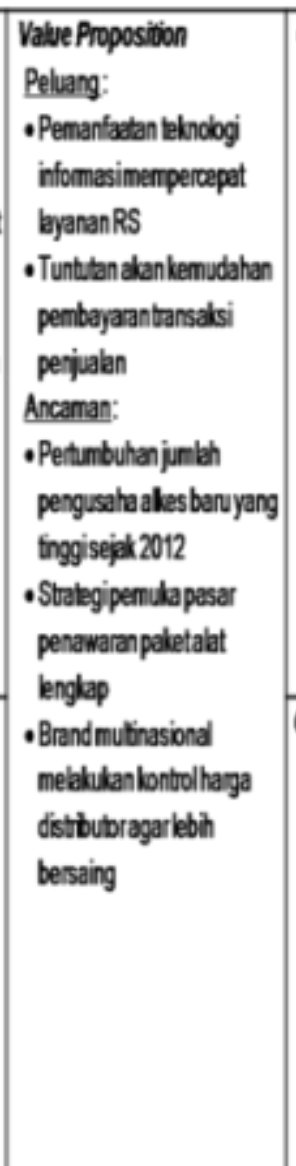 } & 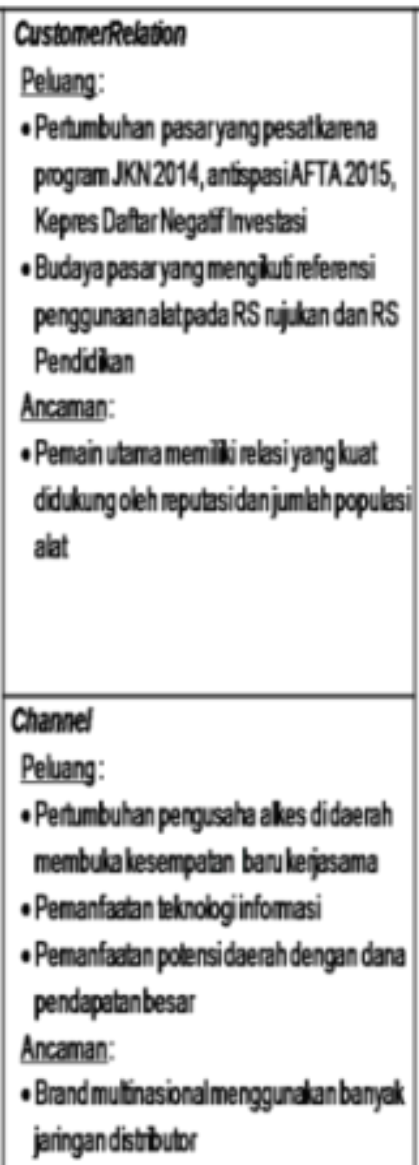 & 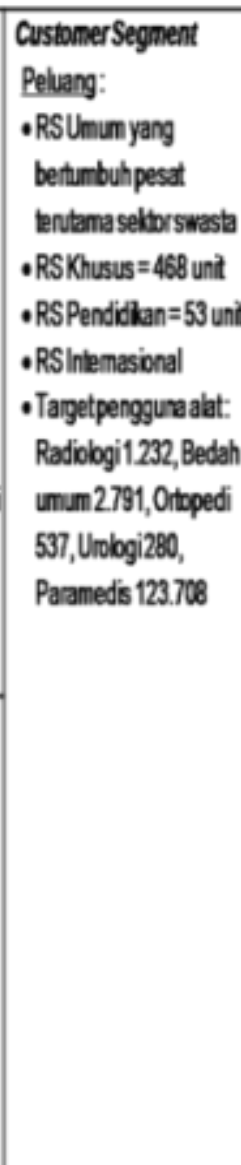 \\
\hline \multicolumn{3}{|c|}{ 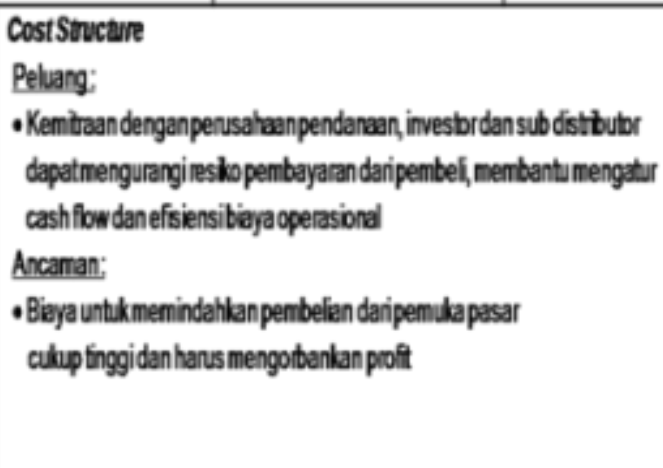 } & \multicolumn{3}{|c|}{ 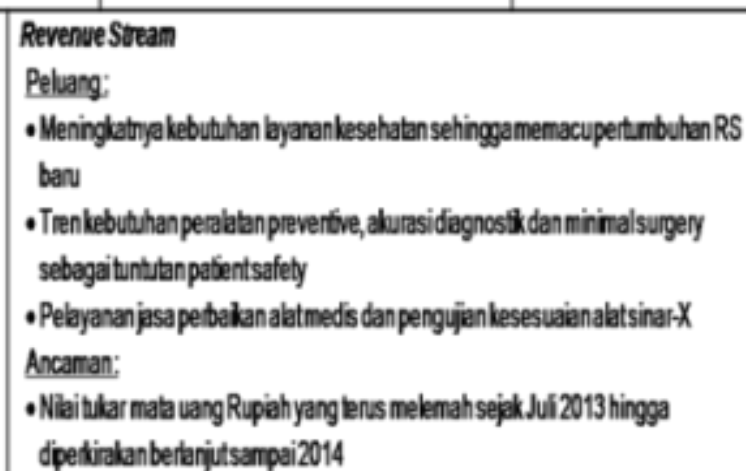 } \\
\hline
\end{tabular}

Gambar 5.

Model Bisnis Peluang dan Ancaman PT. SAV 


\subsection{Kanvas Model Bisnis Masa Depan}

Model bisnis masa depan dibuat dengan memadukan analisis eksternal (peluang dan ancaman) dengan analisis eksternal (kekuatan dan kelemahan).

\subsubsection{Segment}

Penetapan rumah sakit kelas A dan B dirasa telah tepat, namun untuk dapat meningkatkan pendapatan sasaran perlu lebih spesifik pada rumah sakit pendidikan dan rumah sakit khusus yang termasuk dalam kategori type A dan B. Selain itu rumah sakit berskala Internasional juga merupakan pangsa pasar yang potensial sebagai key account bagi target pemasaran mengingat jenis ini sangat memperhatikan kualitas dalam pembelian investasi alat mengikuti panduan standard lembaga akreditasi internasional. Perusahaan supplier pemain tender pengadaan alat instansi pemerintah dan sub distributor dapat dijadikan sebagai segmen baru dalam upaya membentuk strategi kemitraan dan konsorsium guna mengatasi keterbatasan perusahaan untuk dapat memenuhi semua kebutuhan peralatan bagi suatu rumah sakit.

\subsubsection{Value Propositions}

PT. SAV akan memasarkan alat kesehatan di 4 bidang utama : radiologi, bedah, ortopedi dan urologi dengan cara melakukan integrasi dengan grup usaha lain seperti PT.SAP, PT.OGS dan PT. Mensch Pharma melalui aktifitas :

- Joint promotion yaitu melakukan aktifitas promosi bersama anak perusahaan Graha Farma yang lain.

- Melakukan paket bundling dengan produk farmasi Ethical yang memiliki potensi reguler pemakaian yang besar dengan karakter produk yang spesifik dan harga jual yang tinggi.

PT.SAV perlu menjalin kerjasama dengan perusahaan keuangan untuk menyediakan kemudahan pembiayaan dan perusahaan investor medik yang menyewakan alat kepada rumah sakit tertentu dengan imbalan bagi hasil tiap tindakan pasien. Kekuatan inti pada fokus pemasaran produk radiologi, ortopedic, urologi dan peralatan bedah perlu terus dijaga agar dan konsisten menggarap potensi pasar pada area tersebut. Kecepatan respon layanan servis dapat dijadikan sebagai nilai jual dengan memberikan jaminan response time dalam jangka waktu tertentu yang lebih pasti.

Value proposition yang hendak dicapai secara kualitatif adalah menciptakan kepuasan bagi pelanggan dengan cara menawarkan solusi kemudahan cara pembayaran dan secara kuantitatif adalah memberikan kecepatan layanan purna jual bergaransi.

\subsubsection{Channels}

Sebagai perusahaan yang baru memulai usahanya, PT. SAV tidak memiliki pilihan lain selain harus memanfaatkan segala sarana dan saluran untuk menyampaikan pesan informasi produk, layanan serta value proposition kepada segmen pasar yang dituju. Sinergi dengan anak perusahaan lain dapat memperkuat keyakinan calon pelanggan selain juga memperluas area penyebaran informasi. Propinsi, kota atau kabupaten dengan pendapatan daerah yang besar dan taraf ekonomi masyarakat yang tinggi harus mendapatkan perhatian khusus oleh tim marketing untuk mengelola potensi. Pemanfaatan saluran konvensional, kegiatan personal selling dan pameran harus didukung promosi melalui oleh moda saluran lain untuk memperluas cakupan area. Perlu memanfaatkan teknologi digital melalui publikasi informasi pada website perusahaan dan menyediakan portal pemesanan on line 
maupun email, membentuk komunitas user melalui social media.

\subsubsection{Customer Relationship}

Kegiatan customer relation yang dilakukan PT.SAV lebih bertujuan untuk mengakuisisi pelanggan baru. Strategi apa yang akan dipilih dalam menghadapi pesaing utama, apakah secara frontal atau secara gerilya menghantam pesaing. Serangan terbuka tentunya akan mengundang reaksi perlawanan pesaing untuk mematikan potensi bagi PT. SAV. Selain melalui promosi komunikasi dua arah dedicated personal assistance terhadap user potensial, perlu adanya investasi kegiatan penyelenggaraan edukasi dan pelatihan aplikasi pengenalan teknologi alat terbaru untuk menciptakan minat user terhadap adopsi peralatan baru. Hubungan pelanggan dijaga dengan memberikan layanan purna jual sesuai komitmen dan lebih bersifat proaktif.

\subsubsection{Revenue Streams}

Melalui cabang perwakilan tim pemasaran pada kota besar di area potensial dengan pendapatan daerah yang tinggi diharapkan dapat memanfaatkan peluang belanja anggaran daerah pembangunan infrastruktur kesehatan dan menangkap peluang pertumbuhan rumah sakit swasta. Peralatan yang memerlukan pemakaian disposable seperti mesin X-ray, ESWL, perangkat kamar bedah dan sterilisator diberdayakan untuk mendatangkan pendapatan berulang melalui pembelian rutin bahan habis pakainya. Tim teknis servis yang terlatih dengan peralatan kerja yang memadai dapat diberdayakan untuk melayani jasa kalibrasi, perbaikan dan perawatan peralatan merek lain yang sejenis, menjadikan divisi servis sebagai bisnis unit yang dapat mendatangkan keuntungan (profit center). Tim aplikasi yang dibentuk dari sekelompok tenaga ahli praktisi alat dapat mendatangkan pendapatan dengan cara memasarkan jasa pelatihan lanjutan kepada komunitas pengguna dengan penguasaan ilmu terapan baru maupun refreshment training bagi para operator.

\subsubsection{Key Resources}

Kunci keberhasilan bisnis pemasaran ini sangat bergantung kepada sumber daya tim marketing, visi dan kompetensi pemimpin, serta jaringan yang dimiliki oleh perusahaan. Keahlian komunikasi dan jiwa pelayanan tim marketing perlu senantiasa untuk ditingkatkan, diberlakukan sistem reward and punishment yang adil untuk menumbuhkan iklim kompetisi secara positif, sistem skema insentif yang menarik, serta jaminan kesempatan berkarir yang terprogram. Aset utama berupa merek dagang produk yang dikenal kualitasnya secara internasional merupakan citra positif yang mempermudah penerimaan produk oleh calon pelanggan. Sinergi antar sumber daya marketing dan merek dagang yang diageni harus terbentuk dalam memperkuat brand awareness pada pasar domestik.Tim servis yang mendukung aktifitas purna jual juga mutlak disiapkan dengan jumlah personil yang sesuai kebutuhan.Sinergi bisnis antar lini usaha harus terintegrasi melalui koordinasi dari bagian Corporate Project menjadikan kekuatan baru dalam pelayanan produk healthcare. Tim IT penunjang teknologi informasi perlu diadakan guna mendukung inovasi promosi pemasaran.

\subsubsection{Key Activities}

Kegiatan utama pemasaran yang penting dilakukan adalah upaya penciptaan kebutuhan (creating demand) terhadap user pengusul untuk menginisiasi proposal pengadaan barang baru maupun unit pengganti atau back up terhadap alat yang 
telah lama digunakan. Hal ini dilakukan melalui aktifitas kunjungan tatap muka dengan user, presentasi formal, mengadakan pelatihan dan workshop aplikasi alat, program trial alat, serta pemberian donasi sampel untuk disposable. Juga dilakukan publikasi promosi melalui pameran alat kesehatan, iklan media profesi kesehatan dan pemanfaatan media website serta telemarketing. Cara yang efektif dapat ditempuh dengan masuk pada jaringan tingkat manajemen pelanggan rumah sakit yang telah dilayani oleh grup usaha PT. OGS, PT. SAP dan tim PT. Mensch Farma.

\subsubsection{Key Partnership}

Kekuatan yang dimiliki saat ini adalah bermitra dengan empat produsen alat Hologic, Del Medical, VG Medical, dan MTS yang memilki kualitas produk yang unggul. Sumber pendapatan berulang dapat diperoleh dari konsumabel film radiologi dari produsen Primax. Kemitraan kunci lain melalui kerjasama dengan sub-distributor, lembaga pendanaan bank maupun swasta, serta investor peralatan kesehatan. Penunjukan mitra sub-dealer diharapkan berdampak positif terhadap jangkauan pasar yang lebih luas, menciptakan sinergi di lapangan dengan tim marketing PT. SAV dan sekaligus menghemat biaya operasional. Lembaga pendanaan memberikan alternatif penyelesaian masalah jika pembeli memiliki kendala ketersediaan dana sementara kebutuhan tidak dapat ditunda.

\subsubsection{Cost Structure}

Segala kegiatan yang bertujuan untuk menyampaikan value proposition guna memperoleh pendapatan harus senantiasa diikuti dengan kontrol terhadap biaya operasional. Perlu selektif dalam memilih kegiatan dan media promosi agar prinsip efisiensi dan efektifitas dapat tercapai. Sharing budget promosi dengan key partners dan cost operasional bagian keuangan, personalia dan general affairs dilakukan secara terpusat di grup usaha dapat ditempuh untuk meringankan biaya. Biaya rutin infrastruktur dan operasional (personal expenses, marketing expenses, dan general expenses) dikendalikan sesuai tingkat kepentingannya, sponsorship dan biaya promosi lain harus diukur pengaruhnya terhadap penjualan menjaga agar harga jual alat yang ditawarkan menjadi lebih kompetitif.

Pada Gambar 6. berikut ini ditunjukkan model bisnis PT. SAV masa datang. 


\begin{tabular}{|c|c|c|c|c|c|}
\hline $\begin{array}{l}\text { - Sub distributor daerah } \\
\text { - Konsorsium distributor }\end{array}$ & $\begin{array}{l}\text { Key Activities } \\
\text { - Create demand } \\
\text { melalui workshop } \\
\text { - Joint promotion } \\
\text { grup usaha Graha } \\
\text { - Pembinaan sub } \\
\text { distributor dan mitra } \\
\text { usaha } \\
\text { - Penawaran jasa } \\
\text { servis dan kalibrasi } \\
\text { - Pengelolaan media } \\
\text { digital (website \& } \\
\text { sosial media) }\end{array}$ & \multicolumn{2}{|c|}{$\begin{array}{l}\text { Value Proposition } \\
\text { - Total solution pada } 4 \\
\text { bidang utama : radiologi, } \\
\text { bedah, } \\
\text { ortopedi, urologi } \\
\text { - Kontrak bundling } \\
\text { dengan pemakaian } \\
\text { produk farmasi } \\
\text { - Paket angsuran } \\
\text { - Paket kerjasama } \\
\text { operasi melalui } \\
\text { investor } \\
\text { - Jaminan respon } \\
\text { purna jual yang cepat } \\
\text { dan akurat } \\
\text { - Jasa servis perbaikan } \\
\text { dan kalibrasi } \\
\text { - Jasa pelatihan } \\
\text { (aplikasi) }\end{array}$} & $\begin{array}{l}\text { Customer Relationship } \\
\text { - Fokus pada kebutuhan } \\
\text { user, daripada mengikuti } \\
\text { pesaing } \\
\text { - Membangun kompetensi } \\
\text { user melalui sarana } \\
\text { workshop dan pelatihan } \\
\text { - Jasa servis yang pro aktif } \\
\text { dan berkomitmen } \\
\text { - Penetrasi pada jaringan } \\
\text { pelanggan Graha } \\
\text { Channels } \\
\text { - Cabang pemasaran pada } \\
\text { area potensial } \\
\text { - Sub- distributor dan mitra } \\
\text { usaha } \\
\text { - Grup usaha Graha } \\
\text { - Key opinion leader / brand } \\
\text { ambassador } \\
\text { - Promosi interaktif : } \\
\text { pameran profesi } \\
\text { user, online } \\
\text { website, social } \\
\text { media, telemarketing }\end{array}$ & $\begin{array}{l}\text { Customer Segments } \\
\text { - RS tipe A\& B } \\
\text { oRS Pendidikan } \\
\text { oRS Khusus : } \\
\text { diagnostik, bedah, } \\
\text { ortopedi, urologi } \\
\text { - RS internasional } \\
\text { - Perusahaan tender } \\
\text { dan sub- distributor }\end{array}$ \\
\hline \multicolumn{3}{|c|}{$\begin{array}{l}\text { Cost Structure } \\
\text { - Infrastruktur \& cost sharing biaya pendukung operasional } \\
\text { - Akuisisi \& pengembangan sumber daya pemasaran } \\
\text { dan servis } \\
\text { - Biaya promosi untuk membangun brand awareness } \\
\text { - Pengendalian stok barang } \\
\text { - Sharing budget dengan key partners }\end{array}$} & \multicolumn{3}{|c|}{$\begin{array}{l}\text { Revenue Streams } \\
\text { - Penjualan unit alat investasi preventive, diganostic dan treatment } \\
\text { - Memberdayakan potensi penjualan berulang dari disposible film } \\
\text { xray, alat treatment dan kelengkapan bedah } \\
\text { - Menjadikan divisi servis dan aplikasi sebagai profit center }\end{array}$} \\
\hline
\end{tabular}

Gambar 6.

Model Bisnis PT. SAV Masa Datang 


\section{KESIMPULAN DAN SARAN}

\subsection{Kesimpulan}

Seiring pesatnya pembangunan sektor kesehatan, minat pengusaha bidang penyalur alat kesehatan juga bertumbuh. Situasi persaingan ketat diantara pengusaha harus diantisipasi oleh PT. SAV dengan menerapkan model dan strategi bisnis yang tepat. Perusahaan harus menata dan mengoptimalkan sumber daya internal, melaksanakan aktifitas pemasaran dengan penciptaan customer value yang tidak mudah ditiru, melakukan kontrol terhadap pengeluaran biaya operasional agar memiliki daya saing, serta mengalokasikan keuntungan bagi upaya pengembangan usaha untuk melestarikan pertumbuhan perusahaan.

Segmentasi pelanggan dipilih pada karakteristik pasar yang paling tepat dapat mengadopsi jenis dan kualitas peralatan yang disediakan.

Penciptaan diferensiasi nilai pelanggan dengan menawarkan kemudahan dan keringanan model transaksi penjualan melalui kerjasama lintas anak usaha grup Graha Farma, lembaga permodalan bank maupun swasta, serta menjaga konsistensi fokus menawarkan dan melayani pada sinergi empat bidang target utama yaitu radiologi, ruang bedah, ortopedi, dan urologi.

Pendistribusian customer value dapat memanfaatkan jaringan pelanggan grup usaha saat ini, menempatkan perwakilan cabang pemasaran pada area yang paling potensial, menjalin kerjasama pemasaran dengan pihak eksternal dan komunitas user alat, serta melakukan terobosan promosi yang kreatif dan efektif melalui digital marketing dan media komunikasi.

Perhatian utama bagi PT.SAV adalah mendapatkan pelanggan baru melalui pendekatan kepada komunitas pengguna dengan upaya menciptakan kebutuhan baru.
Pendapatan dapat diperoleh melalui aktifitas jaringan pemasaran internal, grup usaha maupun kemitraan eksternal. Produk disposable dan peralatan investasi yang memerlukan bahan habis pakai harus diberdayakan guna memperoleh pendapatan secara berulang dan berkelanjutan. Divisi teknik melalui layanan jasa perbaikan, penjualan spare part dan pengujian alat mendatangkan pendapatan tambahan sekaligus membuka jalinan hubungan dengan calon pembeli alat baru.

Sumber daya perusahaan dan brand yang diageni harus bersinergi dalam kepentingan membangun brand awareness bersama untuk memperkuat dan memperluas pengaruh pada pasar. Beberapa posisi jabatan baru yang mengisi fungsi pendukung pemasaran perlu dibentuk agar penyampaian nilai kepada pelanggan dapat berjalan lebih efektif dan terorganisir.

Aktifitas pemasaran dilakukan dengan penciptaan kebutuhan melalui berbagai kegiatan promotif yang berfokus kepada user. Divisi servis dapat membuka jalan dalam membina hubungan dengan calon pembeli melalui layanan teknis perawatan alat.

Kepercayaan mitra produsen dan mitra usaha lokal perlu dijaga dalam rangka menghasilkan keuntungan bersama.

Aktifitas operasional harus diiringi dengan pengelolaan efisiensi biaya dan upaya kontrol lain untuk mengendalikan resiko kerugian yang mungkin timbul.

Rekomendasi bagi PT. SAV dalam rangka mengembangkan pertumbuhan usaha pada periode 2014-2016:

- Melakukan perubahan model bisnis dari yang sebelumnya masih bersifat umum menjadi lebih spesifik dan unik.

- Memposisikan diri sebagai spesialis fokus bidang radiologi, ortopedi, urologi dan ruang bedah dengan meningkatkan kompetensi. 
- Membuat usulan struktur organisasi baru sehubungan dengan dibutuhkannya fungsi jabatan baru yaitu Corporate Project Manager, IT Marketing, Product Specialist, Corporate Finance/ HR/ IT, Divisi unit bisnis Servis dan Aplikasi. Penambahan jabatan ini secara otomatis akan merubah proses dan sistem bisnis yang berlaku menjadi lebih optimal dalam menangkap peluang pasar.

\subsection{Saran}

Saran penulis bagi penelitian industri pemasaran alat kesehatan selanjutnya :

- Model bisnis kanvas merupakan cara efektif dalam mengevaluasi dan menyempurnakan model bisnis yang sedang berjalan. Model bisnis lain dari Timmers (1998) atau Rappa (2010) juga dapat diterapkan melalui pendekatan perangkat analisis yang berbeda.

- Penilitian industri alat kesehatan memiliki kendala karena tidak tersedianya data pangsa pasar masing - masing brand, jenis produk dan pelaku pemasaran baik dari Kemenkes, Perhimpunan Rumah Sakit maupun asosiasi user seperti pada industri Farmasi. Oleh karenanya diperlukan upaya pendataan secara sampling yang memerlukan cukup waktu dan biaya untuk menjangkau sejumlah rumah sakit yang menjadi target obyek pengumpulan data. 


\section{DAFTAR PUSTAKA}

Alexander Osterwalder \& Yves Pigneur. 2012 ,Business Model Generation, PT. Elex Media Computindo, Jakarta.

Hendrawan Supratikno \& Anton Wachidin Widjaja. 2005. Advanced Strategic Management, PT. Gramedia Pustaka Utama, Jakarta.

Tim PPM Manajemen.2012. Business Model Canvas, PPM, Jakarta.

Fred R. David. 1991 .Strategic Management: Strategic Planning. Macmillan, New York.

Philip Kotler \& Gary Amstrong.1994. Dasar - Dasar Pemasaran. CV. Intermedia, Jakarta.

Michael d. Hut \& Thomas W. Specch. 1998. Business Marketing ManagementA strategic view of industrial and organizational markets, The Drydenn Press, New York.

Hermawan Kertajaya.2010. Connect Surving New Wave Marketing, PT. Gramedia Pustaka Utama, Jakarta.

Company Profile Graha Holding dan SAV 2012. Tangerang Selatan.

Hospital Directory 2013 - 2014, Infomedia, Jakarta.

www.depkes.go.id, Kementrian KesehatanRepublik Indonesia, 2013.

www.bps.go.id, Biro Pusat Statistik, 2013.

www.oecd.org/health/healthdata, Organization for Economic Co-operation and Development, 2013.

http://id.wikipedia.org/wiki/Daftarprovinsi_Indonesia_menurut_PDRB_per_kapita 